Marquette University

e-Publications@Marquette

Social and Cultural Sciences Faculty Research and

Publications

Social and Cultural Sciences, Department of

$12-1-2001$

\title{
Elderly Narrative Reflections on the Contradictions in Turkish Village Family Life after Migration of Adult Children
}

Roberta Coles

Marquette University, roberta.coles@marquette.edu

Accepted version. Journal of Aging Studies, Vol. 15, No. 4 (December 2001): 383-406. DOI. (C) 2001 Elsevier. Used with permission.

NOTICE: this is the author's version of a work that was accepted for publication in Journal of Aging Studies. Changes resulting from the publishing process, such as peer review, editing, corrections, structural formatting, and other quality control mechanisms may not be reflected in this document. Changes may have been made to this work since it was submitted for publication. A definitive version was subsequently published in Journal of Aging Studies, VOL 15, ISSUE\# 4, (December 2001) DOI. 


\title{
Elderly Narrative Reflections On the Contradictions in Turkish Village Family Life After Migration of Adult Children
}

\author{
Roberta L. Coles \\ Social and Cultural Sciences, Marquette University \\ Milwaukee, WI
}

\begin{abstract}
International and domestic labor migrations are changing the face of many countries. Those economic and demographic transitions collide with cultural expectations and ways of conducting intergenerational relations. This paper is a narrative analysis of some of those changes from the perspective of the elderly who remain behind in a small village in central Turkey. In particular, their narratives focus on filial expectations of sons and daughters, the status of mothers-in-law, health and economic well-being, and the future of village life. While these "left behind" elderly feel a loss of status and control and fear for their futures as their children pursue lifestyles unfamiliar and threatening to them, they are nevertheless gradually negotiating these changes and redefining late life to adapt to new circumstances and maintain their family relations.
\end{abstract}

\section{Introduction}

In today's global economy, international and domestic labor migrations are commonplace. The ebb and flow of capital, unemployment, wage levels, job security, levels of technology, and 
skills within and across countries, as well as war and natural disasters, contribute to high levels of labor migration. As of the early 1990s, about 100 million people lived outside their country of citizenship. However, this accounts for less than $2 \%$ of the world's population (Bloom \& Brender, 1993, p. 21). The more significant labor migration has been internal rural-to-urban migrations, which have changed the demographic face of most, if not all, countries during the twentieth century.

In addition to the economic and political changes that are both a cause and an effect of these migrations, family relations have been affected as well. Numerous studies have documented the effects of migration on the migrants themselves in terms of acculturation, setting up new communities, and reestablishing kin networks. ${ }^{1}$ An increasing number are focusing on the impact migration has on gender roles of single or married migrants. (For instance, Khaled, 1995; Kocturk, 1992; Tienda \& Booth, 1991; Vandsemb, 1995 present some general findings.) A few have begun to focus on elderly migrants (Becker \& Beyene, 1999; Goldberg, 1996; Kamo \& Zhou, 1994; Olmedo, 1999; Thomas, 1992), but there has been little, if any, research highlighting the effect the migration of families has on the nonmigrant kin. Since it is most often young men or young families who migrate, the nonmigrant kin are frequently the elderly who remain in the rural areas and/or in the country of origin. Many scholars have been understandably concerned with the benefits of remittances for the sending country or the remaining individual family members, but intergenerational conflict, filial expectations, familial power structures, and general well-being are of equal concern to the aging kin.

This paper initiates exploration of this phenomenon and gives voice to this group of nonmigrant elderly through a case study of elderly villagers in north central Turkey, all of whom have had adult children migrate to other countries or to larger cities in Turkey. The paper briefly describes the nature of migration in Turkey and the effect it has had on village life in general. Then, through interviews with one group of village elders, the paper illustrates the frustrations the elderly feel as they try to render coherent the inevitable contradictions they 
experience between old and new circumstances and between competing values.

\section{Narration as a way of balancing contradictions}

Bruner (1986, 1996, 1999) and Randall (1999) argue that "narrative intelligence" is one of a number of types of intelligence for which humans have varying capacity. Aging may enhance or detract from that capacity. McAdams (1996) suggests that the "elderly person looks upon his or her life as something that has been and must now be reviewed or evaluated as a near-finished product, a story that may be accepted (integrity) or rejected (despair) but which can no longer be substantially changed" (p. 136). Yet, since no one knows exactly when his or her life will end nor whether the story will be in the genre of comedy, tragedy, adventure, etc., we are at the same time, as Polkinghorne (1988) proposes, in the middle of our stories, needing to be ready to revise as new events occur.

Kierkgaard said that we live life forward but understand it backward (Bruner, 1999, p. 8). Yet, in practice, narration is not so linear; it is rather cyclical or perhaps even chaotic, because we also periodically attempt to tell our stories into the future. That is, we envision or attempt to foresee our futures (we may even hire fortunetellers or prophets to do it for us!), and in so doing, we build hopes, expectations, and fears of the future. When the actual events finally occur, they may not conform to the imagined denouement. Major social transitions, such as demographic changes caused by waves of migration, inevitably lead to disruption in established ways of doing and thinking family relations. In addition, therein lie the contradictions, the imbalances, or imbroglios that compel us to narrate, to restore order, and to negotiate the inevitable disappointments.

The literature on narration appears to hold the assumption that narrative is driven by the need to create coherence and restore order (Linde, 1993). Stories are therapeutic means of coping with disruptions and healing discontinuities (Becker \& Beyene, 1999; Mattingly \& Garro, 1994; Turner, 1980). However, the state of coherence and order is not always successfully attained. Sometimes

Journal of Aging Studies, Vol 15, No. 4 (December 2001): pg. 383-406. DOI. This article is (C) Elsevier and permission has been granted for this version to appear in e-Publications@Marquette. Elsevier does not grant permission for this article to be further copied/distributed or hosted elsewhere without the express permission from Elsevier. 
narrators die before they reach such a conclusion, and sometimes, just as married couples must often agree to disagree, narrators must reconcile themselves to live with contradictions. This is neither impossible nor unusual; most collective and individual cultural discourses embody competing and contradictory values simultaneously. People draw upon one discourse in some situations and, apparently without much incongruity, call upon a contradictory discourse in other circumstances.

In the migration context discussed here, older nonmigrant kin must restructure their daily lives to accommodate the loss of proximal emotional support, status and role certainty, and the labor that the presence of more youthful family members had provided. They must also restructure their values and expectations to accommodate the contradictions involved in such major physical and cultural transitions that are the result of economic change and mass migrant flows. The act of speaking their stories or articulating the myriad of changes may bring some consolation and relief or shed new light through new interpretations, but it is not uncommon that the narrators reach no satisfactory resolution as they maneuver through this minefield of changes.

I first became aware of the familial impact of these changes through young adult Turkish migrants living in the United States, friends who expressed some guilt that they were failing to take care of their parents as they had assumed they would do if they had remained in Turkey. Then, in 1992, I visited a village, which I am calling Sirna, in north central Turkey. This was the birthplace of one of my migrant friends. I noticed that there were very few young people and children in the village, and the topic of how life had changed was frequently apparent in our conversations. Their statements of pride in their children's accomplishments were interspersed with complaints of or disappointment in their children's failure to meet their filial expectations. In the intervening years, I researched migration and Turkish family life further, and then, in 1999, I returned to Sirna to conduct interviews.

As a case study, this paper looks at migration from the perspective not of the migrants but of their elderly parents who remain

Journal of Aging Studies, Vol 15, No. 4 (December 2001): pg. 383-406. DOI. This article is (C) Elsevier and permission has been granted for this version to appear in e-Publications@Marquette. Elsevier does not grant permission for this article to be further copied/distributed or hosted elsewhere without the express permission from Elsevier. 
in the rural areas of sending countries or sending regions within a country. Narratives were gathered through informal semistructured interviews of families in this small village during the summer of 1999. I was able to interview about 20 of the households in Sirna, which is equivalent to about one-half of the households residing in the village in 1999. Since I was interested mostly in the perspective of the elderly, I concentrated on households containing people at least 50 years old. Interviews were generally conducted through informal group conversations or with individuals in their homes. As a woman, I had easier access to women, and even in mixed company, women were more likely to speak to the questions I posed. Since I do not speak fluent Turkish, I had to rely on a translator (a person who had grown up in the village and was trusted by the villagers) to ask many of the questions and interpret their answers for me. Questions focused on the number, gender, and residence of their children, what life was like in the village when they were younger, their contacts with their nonresident children, and their expectations and concerns for late life. I found that while most of the elderly were faring relatively well, they expressed disappointment in unfulfilled late-life expectations, difficulty reconciling these expectations with the new circumstances, fear for their emotional and medical future and the future of their village, and concern for the loss of the traditional venue for status among elderly.

\section{Turkish migration patterns and its impact upon villages}

In terms of international labor migrations, Turkey has primarily been a sending country. As of 1995, it is estimated that more than three million Turks reside abroad (Goldberg, 1996). Approximately 93\% lived in Europe (mostly in Germany) and about 5\% lived in Arab countries (Omran \& Roudi, 1993, p. 24). The stream of Turkish labor to Europe began in the 1950s as Europe rebuilt after World War II. Recruitment agreements between Germany, the Netherlands, Belgium, Austria, France, Sweden, and Turkey were all signed in the 1960s, encouraging a flow of male workers. Family reunification flows accounted for much of the migration in the 1980s due to more restrictive immigration policies and repressed economic conditions in Europe (Goldberg, 1996).

Journal of Aging Studies, Vol 15, No. 4 (December 2001): pg. 383-406. DOI. This article is @ Elsevier and permission has been granted for this version to appear in e-Publications@Marquette. Elsevier does not grant permission for this article to be further copied/distributed or hosted elsewhere without the express permission from Elsevier. 
As with most other countries, however, it is the rural-to-urban migration that has accounted for the largest part of population shifts in Turkey. Between 1950 and 1980, Turkey's rural population increased $60 \%$, but Turkey's urban population quadrupled. It is estimated that about one-fourth of Turkey's population (based on 1980 figures) migrated to the cities (Tunali, 1996, p. 31). Population statistics by province from 1985 to 1990 indicate continued rural-to-urban population shifts. Much of this shift has not only been from rural areas to cities but also from east to west. $^{2}$ The northern and eastern regions of Turkey are largely mountainous, more rural, and less developed than the western half of Turkey, where the largest cities are located. These regional inequalities increase the potential for large migration flows (Tunali, 1996, p. 34). The population of Eastern Anatolia ${ }^{3}$ as a whole dropped by 468,503 between 1985 and 1990, and Central Anatolia's population dropped by 150,106 during those same years, whereas Istanbul, Ankara, Izmir, and Bursa (all cities located in the West) had population increases (State Institute of Statistics, 1999).

These shifts are reflected in a labor sector shift as well. Before World War II, only $20 \%$ of Turkey's population were in formal wage labor; $80 \%$ lived in the countryside and was mostly in agriculture (Ilcan, 1994, p. 554). By 1980, the percentage of Turkey's population employed in formal wage labor had increased to $45 \%$ (Tunali, 1996, p. 32 ) and to $57 \%$ by 1996 (State Institute of Statistics, 1999).

These national populations shifts are consequently reflected in a north central mountainous district I am calling Raaza, which has 131 villages, of which Sirna is one. Since 1985, every single one of the 131 villages has experienced a population decline. Sirna's population was 498 in $1985 .{ }^{4}$ By 1998 , its population was 209. Despite the more than $50 \%$ decline in population, Sirna remains one of the largest villages in the district because such declines have been typical of all the villages in the district. About $86 \%$ of the villages have had population declines of $50 \%$ or more and $23 \%$ have had at least a $75 \%$ decline. Therefore, even in the district of Raaza, the urban proportion of the population is larger than the rural. The population of the town of Raaza is 16,670 , while the population of all 131 villages combined is 12,841 (Mahirogullari, 1996). Given that these demographic changes are occurring nationwide, it would not be unreasonable to assume that the

Journal of Aging Studies, Vol 15, No. 4 (December 2001): pg. 383-406. DOI. This article is (C) Elsevier and permission has been granted for this version to appear in e-Publications@Marquette. Elsevier does not grant permission for this article to be further copied/distributed or hosted elsewhere without the express permission from Elsevier. 
findings stemming from this small case study are being repeated on a wider scale.

\section{Sirna's community and elderly living patterns}

The villages in the district of Raaza are a mix of cash cropping and subsistence farming. Most Sirna families cultivate some wheat (for flour and bulgur), oats, and/or alfalfa (to feed the animals), a portion of which may be sold or bartered in internal markets for other goods or services. Several of the younger families have large herds of cow for market purposes, but most of the elderly households maintain only a few cows for their dairy products (milk, yogurt, and cheese) and chickens for eggs. Usually, each household will have one or two small vegetable gardens, again for their own use or to barter within the village. Grains and dairy products are the main staples of the village diet.

An increase in technology (i.e., primarily tractors) has resulted in growing inequality in the village. Nineteen of Sirna's families own tractors, so they are essentially the only families who now cash-crop full-time. The tractor owners can cultivate large tracts of land for the market, and consequently, they can also can afford larger herds of cows and sheep. Those without tractors (primarily the older households) have had to leave many outlying fields lie fallow. These households are either retired, farm at a subsistence level, or hold the few service sector jobs available in the village. For instance, one 40something father of seven is the village bus driver. He makes several daily round trips between nearby villages and towns. Another father of three in his late $30 \mathrm{~s}$ is the village Imam, who is paid by the state to act as the religious leader of the village. (Most of the villagers doubt his religious commitment. They assume he would not be there if it were not for the state salary he receives). Another man in his $40 \mathrm{~s}$ is the mayor of the town. There is only one closet-sized store in the village, and it is run only in the summer by an elderly man.

Virtually all of the villages in the Raaza district have electricity and telephones. About $90 \%$ of them have plumbed water (though that may mean only one spigot into the house; toilet facilities are frequently outhouses). Sirna is one of the villages that has all three of

Journal of Aging Studies, Vol 15, No. 4 (December 2001): pg. 383-406. DOI. This article is (C) Elsevier and permission has been granted for this version to appear in e-Publications@Marquette. Elsevier does not grant permission for this article to be further copied/distributed or hosted elsewhere without the express permission from Elsevier. 
these utilities, but most of these signs of modernization came within the last $10-30$ years. As late as 20-30 years ago, many of the families had to walk a mile or so to obtain water from a mountain spring. My key informant family obtained a phone only 8 years ago.

Only $39 \%$ of the villages have elementary schools; Sirna is one of them (Ekmek-Cioglu, 1998, pp. 346-348). Even with modernization, however, it is unlikely that more schools will be built in these villages. A growing indication of this, according to Sabri Cataltepe (1999), secretary of the technical high school in the nearby town of Raaza, is the government's recent policy of paying for village children to be bussed into nearby towns for school, because many teachers refuse to be placed in village schools and the school-age population in the villages is declining, especially in the eastern part of the country.

Less than $2 \%$ of the villages have medical facilities such as a nurse or clinic (Ekmek-Cioglu 1998, pp. 346-348). Sirna is not one of them.

The mayor of Sirna estimates that its 200 people reside in about 30-40 households and that there are fewer than 40 school-aged or younger children. Due to the higher birthrates of village families, most of these children are probably concentrated in about 8 to 12 households. Even then, it is not necessarily an indication that these households are run by young parents. One man in his $60 \mathrm{~s}$ is the single parent of two young girls because he married a second wife late in life (hoping to replace his only son who died) and then ousted her because she was "acting crazy."

As shown in Table 1, the 31 elderly people I interviewed lived in 20 households. About 16\% of them were in their 50 s, $42 \%$ were in their 60 s, $35 \%$ were in their 70 s, and $6 \%$ were in their 80 s. I use decades rather than specific ages because many of the older villagers can only estimate their ages. It is uncommon for villagers to remember and celebrate birthdays, and when these elderly were born, parents often did not get around to registering their children's births (which most often occurred at home) until a couple of years later. Moreover, male children were sometimes registered as being 1 or 2

Journal of Aging Studies, Vol 15, No. 4 (December 2001): pg. 383-406. DOI. This article is (C) Elsevier and permission has been granted for this version to appear in e-Publications@Marquette. Elsevier does not grant permission for this article to be further copied/distributed or hosted elsewhere without the express permission from Elsevier. 
years older than they were so that they could get their military service over earlier and begin families. Therefore, birth dates in the local and district registries are more often estimates than actual.

Eleven (55\%) of the 20 households I interviewed contained elderly couples, eight ( $40 \%$ ) contained widows (seven) or widowers (one), and one (5\%) contained a separated/divorced man. Together, they have 102 living adult children, 52 sons and 50 daughters. Only eight of these children live in the village (three of those are employed in the service sector mentioned above - the mayor, the Imam, and the bus driver). The vast majority (84) of the adult children reside in Istanbul, and six live in small towns or cities elsewhere in Turkey. Four are overseas.

These migration flows of the last 40-50 years, combined with the increased life expectancy over this past century, have contributed to a greying of the village. Although my sample was not inclusive of all the elderly in the village, the 30 elderly who were 60 or older in my sample represent about $12 \%$ of Sirna's population. In the national population, people over 65 represent only $6 \%$ of Turkey's people. While both my figures and the national statistics suffer from the aforementioned problems regarding accurate age calculations, the difference is enough to suggest that elderly people may be disproportionately represented in the rural areas.

Moreover, these migrations are creating new residential patterns among elderly Turkish villagers. Generally, two new residential patterns are occurring among these elderly households. More elderly live in the village on a part-time basis using the village as a summer retirement center, and more elderly live outside the traditional extended family. In regard to residential location, five (45\%) of the elderly couples winter in Istanbul and live in the village during the summer months, and six (55\%) of the elderly couples live in the village all year round (Table 2 ). Of the nine single elderly, one-third winter in Istanbul and summer in the village, and the remaining six live in the village all year round. Widows and married couples have a higher likelihood of part-year residence in the village than do the single men. In total, $40 \%$ of this elderly sample live at least half the year outside the village using the village as something akin to a

Journal of Aging Studies, Vol 15, No. 4 (December 2001): pg. 383-406. DOI. This article is (C) Elsevier and permission has been granted for this version to appear in e-Publications@Marquette. Elsevier does not grant permission for this article to be further copied/distributed or hosted elsewhere without the express permission from Elsevier. 
retirement center. While that percentage is still the minority, it is a substantial minority and a growing trend according to the villagers' observations.

As to the pattern of living in nonextended households, recent research (particularly Rasuly-Paleczek, 1996) on Turkish households over time indicates both that the nuclear household is currently the majority household type in Turkey even in villages and that there is considerable ambiguity as to whether multigenerational extended households were ever the majority. However, it does appear that a majority of families, particularly in the village, experience a period of some form of extended household in their life cycle and that extended family households had been (and continue to be) more common in the rural villages than in the large towns and cities. For instance, Erman (1998) indicates a decrease in extended family forms among village families who had migrated to the capital city of Ankara. Only 9-11\% of the households Erman looked at were extended. Nevertheless, even if the incidence of extended family households was never the majority and has declined, it appears to remain the idealized form of household (Rasuly-Paleczek, 1996, pp. 11-12).

As illustrated in Table 3, only one of the six elderly couples who live in the village all year resides with their adult son. The remaining five couples ( $83 \%$ ) live by themselves. Of the six single elderly who reside all year in the village, half (all widows) reside with adult sons in the village; the other half (one divorced man, one widower, and one widow) live alone in the village all year round. Being in the village, fulltime or part-time, makes it much more likely that they will reside in a nonextended family. Taking all the households together, the households of elderly who live in nonextended households all year comprise $55 \%$ (eight households that reside all year in the village and three households who reside part-time in the village).

Being a widow makes one much more likely to live in an extended family household. Nearly $60 \%$ of the widows reside all year in an extended household compared to $18 \%$ of the married couples and neither of the single men (though both of these men still reside with young, unmarried daughters). This finding is supported by other studies, such as Al-Hamad, Flowerdew, and Hayes (1997), who

Journal of Aging Studies, Vol 15, No. 4 (December 2001): pg. 383-406. DOI. This article is (C) Elsevier and permission has been granted for this version to appear in e-Publications@Marquette. Elsevier does not grant permission for this article to be further copied/distributed or hosted elsewhere without the express permission from Elsevier. 
concluded in their study of elderly who migrate to join existing households in England that bereavement was likely to precipitate such a move. Also, Table 3 shows that only one elderly, a widow, lives with her daughter and that is only when she is in Istanbul. I will say more about that later.

\section{Family relations before and after children's migration}

Being alone in late life was not what they expected, and they have high expectations. At least a couple of studies (Lee and Netzer, 1995; Lee and Coward, 1994, for instance) indicates that rural elderly have higher expectations than urban-reared elderly in terms of intergenerational relations and filial responsibility. This may be due to the presumed greater self-reliance of rural families, where family members comprise the labor force of the household economy. Consequently, the authors conclude that rural elderly are more likely to experience disappointment when their expectations are not met.

Sirna's elderly appear to base their expectations on what they experienced as they grew up, married, and raised their own children. Many of Sirna's elderly grew up in extended households, following a patrivirilocal pattern of residence, at least for a period of time. One 70year-old woman, Saliye, explains the typical pattern:

When I was a young bride [16 years old], I lived in my husband's parents' household [the one she still lives in though both sets of in-laws are deceased now]. My in-laws took care of my young children, took the cows and sheep up to the mountain in the summer for grazing or helped the older children separate the chaff from the wheat in harvest. I worked in the field with my husband, cultivating the land and cutting the wheat. I would get up at 4 a.m. and cook for everyone [at times there were 16 people living in their 2-room house] all day too. And I did whatever my husband's parents said. If they needed their hands washed, I poured the water.

While the grandparents' duties changed to account for their age and declining physical strength, they were still considered productive and essential to the household economy. Moreover, grandfathers were

Journal of Aging Studies, Vol 15, No. 4 (December 2001): pg. 383-406. DOI. This article is (C) Elsevier and permission has been granted for this version to appear in e-Publications@Marquette. Elsevier does not grant permission for this article to be further copied/distributed or hosted elsewhere without the express permission from Elsevier. 
still heads of the household and estate until their death. Consequently, they could attain a high status in the village based on their landholdings and size of their families. Grandmothers held power over the domestic sphere, so they managed their daughters-in-law (called gellins) who came to live in their households. According to Duben (1985, p. 87), this power extended over the grandchildren as well; parents often refrained from showing affection to their children in the presence of the grandparents because "the right to show affection to their grandchildren ... belongs to the grandfather and grandmother." The household division of labor and the network of obligations binding child to elder were understood. Most of the grandparents died in the context of their home and family members. After their deaths, it was not uncommon that the sons and their families would continue to share the household for awhile. But, this is not the picture today's elderly see.

I wanted to know how these elderly, who remain in the villages for at least part of the year, perceive and negotiate these changes. In my conversations with the elderly in these 20 households, I found several recurring themes of concern - intergenerational relations, particularly the filial responsibilities of their adult male children, the loss of status for elderly women, their economic and medical wellbeing, and the future of the village.

\subsection{Filial expectations for sons and daughters collide with new realities}

In conversations about children's migration, the elderly speak mostly of their sons. This is explained by two factors: Those more likely to migrate for purposes of employment, education, or military service are young men. Boys and girls who pass the examination that allows them into high school often must leave home to continue their education, because the villages frequently have no schools or only elementary schools. So, leaving home at a young age, such as 12 , to live in a boarding school or to live with distant family members while attending school is fairly common for village children. While this is increasingly common for girls, it has historically been truer for boys. Parents who must spread their resources thin among several children will allow boys those options more often than girls.

Journal of Aging Studies, Vol 15, No. 4 (December 2001): pg. 383-406. DOI. This article is (C) Elsevier and permission has been granted for this version to appear in e-Publications@Marquette. Elsevier does not grant permission for this article to be further copied/distributed or hosted elsewhere without the express permission from Elsevier. 
This is directly related to the second factor. Turkey has traditionally been a patrivirilocal system in which girls marry out of their family and into their husband's natal family. Therefore, investment in daughters is sometimes seen as a waste, though this attitude appears to be changing. However, even when not viewed this way, investment in sons is still more important because boys are seen as social security for their parents. It is assumed that boys will be the financial providers in their families (despite the fact that several elderly reported having unemployed sons married to employed wives or to having sons in dual-income marriages) and that the sons will be the decision makers in the home. As the providers and decision makers, sons theoretically will be the ones able to provide for the parents in their late life and the ones who can impose their parents on their wives either by the more traditional practice of bringing the wife home to the parents' household or by the more recent practice of moving his parents into the new couple's household. Hence, parents have higher expectations of filial responsibility for their sons than they do their daughters, and this was illustrated by the fact that only one elderly person resided with her daughter and only for part of the year.

Daughters, it is assumed, will have less power in their households, particularly if they reside with their in-laws, and their first obligation will be to their in-laws and not to their own parents. For instance, the daughter of one village family is married to the son of another village family. The young couple resides in Istanbul. Nevertheless, the husband's father, who lives all year in the village, requires the daughter-in-law to come to the village each summer and take his cows to the mountain. During my first visit to the village, he would not allow her to leave the mountain even though her brother from overseas was visiting their parents in the village. Therefore, even if the daughters want to provide for their parents financially or by having them move in, they may have to endure a series of negotiations with their husband and perhaps his family. Consequently, the parents see their daughters' commitment to them as tenuous and contingent upon having a generous husband.

One daughter, Hacar, of a couple in their 70s, lives in the nearby town. She comes at least once a month to spend a few days

Journal of Aging Studies, Vol 15, No. 4 (December 2001): pg. 383-406. DOI. This article is (C) Elsevier and permission has been granted for this version to appear in e-Publications@Marquette. Elsevier does not grant permission for this article to be further copied/distributed or hosted elsewhere without the express permission from Elsevier. 
with her elderly parents, whose two sons live in Istanbul or overseas. She helps with heavier chores like cleaning out the cow barn, making dung cakes, baking a month's worth of bread in the village's common ovens, or painting the rooms of the three-room house. Until recently, this daughter was taking care of her mother-in-law who died slowly of complications from diabetes. The daughter, who has three children of her own, says

Honestly? It was a relief when my mother-in-law died [her father-in-law died unexpectedly about a couple of years earlier]. It was all day and all night care. I was exhausted. Now I can spend more time with my parents, although it sometimes makes my husband unhappy because each trip causes me to be away from home for a few days. My life would be easier if my brothers or even sisters lived closer and could share the load.

Hacar also does not get much credit for her efforts on behalf of her parents in the village as a son or daughter-in-law might.

Some village women accuse me of sweating in the village, just so I can get some bulgur and cheese from my mother. They forget that each time I come, I bring goods from the town that my parents can't get in the village. They forget that it would be easier for me to buy the bulgur and cheese rather than clean out my parents' barn or make dung cakes [for fuel in winter] for them.

Hacar is an illustration of the fact that parents commonly attempt to arrange marriages for their daughters to men who are from other towns or who will be leaving the village, because the parents do not expect much help from her. They know she will be saddled with the responsibilities of her husband's family. They also know that village life is hard work for women, and they hope she will marry someone who will heighten her economic status.

For the sons, however, parents traditionally tried to arrange a marriage to a village girl who was able and willing to work (see also Ilcan, 1994, p. 567). Lately, with sons going away for work or education, sometimes at a young age, this has not been so easy to achieve. Parents have less control over the children's future and, consequently, their own. (See Rasuly-Paleczek, 1996, p. 17 for a 
review of literature that also confirms the reduction in authority of parents and an increase in authority for adult sons and their wives.)

These high expectations of sons are colliding with changing occupational structure that has drawn most of their sons away from farming and the village, and the elderly have not yet come to grips with these changing circumstances. Although they are cognizant of the fact that their sons will not likely takeover their household and farming responsibilities, they still act as if their sons (or actually their daughters-in-law) will be their main source of help. However, under the force of migration, it is increasingly likely that their daughters (or they themselves) will be their main caregivers. ${ }^{5}$

It is still the case then that boys are valued over girls. About two-thirds of the people I met in the village expressed some sympathy for me because I had only daughters. "Oglan Yokmu?" ("No boys?"), they would say with sadness for me. Two widowed women whom I talked with cried that they would be better off if they had had sons. One, Merve, lives alone and feels lonely. She says:

I have a daughter who lives right down the road from me. I see her everyday, but I cannot live with her. That would be yakismak [inappropriate]. Even if I did live with her, I would not feel comfortable.

Merve was convinced that her life would be different had she had sons. Merve was married twice, and there were no sons from either marriage. Both of her husbands died, so now it is debatable as to who will inherit the husband's land (the brother of her second husband has laid claim to the land). She assumes if she had a son, he would have inherited the entire land and used it to take care of her. Because she has no sons, she can live under the assumption that she would necessarily be better off in that situation. Old assumptions die hard. The reality is often very different, as the following story painfully illustrates.

On my first visit to Sirna in 1992, I was invited for tea to the home of an elderly couple, Hasan and Bedriye, who were living alone. The husband appeared to be bedridden though able to sit and talk animatedly. This couple had nine sons and no daughters. All of the

Journal of Aging Studies, Vol 15, No. 4 (December 2001): pg. 383-406. DOI. This article is (C) Elsevier and permission has been granted for this version to appear in e-Publications@Marquette. Elsevier does not grant permission for this article to be further copied/distributed or hosted elsewhere without the express permission from Elsevier. 
sons resided in Istanbul. Saliye tells what happened a year or so after my initial meeting.

Hasan and Bedriye traveled to Istanbul to visit their oldest son. Bedriye was feeling that she could no longer handle the farm responsibilities and take care of her husband. She asked her son if she and her husband could come live with him, but he said he didn't have room. This son then asked his other brothers if any of them could take the parents in, but none of them could find the space or thought they could afford to have their parents live with them. So Hasan and Bedriye returned to the village. About two weeks later, Bedriye boiled some eggs and made some tea for her husband. She told him she was going out to get some wood for the fire, but she didn't come back. Two hours later, Hasan went to find her. She was hanging from the rafters in the barn. They say her tongue was hanging six inches out of her mouth! Now where is her husband? Finally with one of the sons in Istanbul.

She concludes with a look that expresses the irony of the situation. Although 5 or 6 years had passed since the suicide, this story was still vivid in the minds of many elderly villagers. Though they still recite what they think they know about the security of sons, they fear that this may happen to them.

\subsection{The rising status of daughters-in-law and declining status of mothers-in-law}

When the patrivirilocal system is in place, the above incident is not as likely to happen. The woman would have had a son and daughter-in-law in her home to help her take care of the ailing husband and farm chores. The advantage for mothers-in-law is not only the extra help but also the power or supervisory capacity that attends her position over her daughter-in-law. After all, it is the daughter-in-law who comes to live in her house and has to abide by her rules and ways of doing things. Now, even for those who live near or with their children, it is often the in-laws who go to live with the son and daughter-in-law in their house and must adjust to their household organization.

Journal of Aging Studies, Vol 15, No. 4 (December 2001): pg. 383-406. DOI. This article is (C) Elsevier and permission has been granted for this version to appear in e-Publications@Marquette. Elsevier does not grant permission for this article to be further copied/distributed or hosted elsewhere without the express permission from Elsevier. 
One elderly couple, Semra and Osman, had two sons and five daughters. One daughter lives in a nearby town. One daughter lives in Germany with her husband. The other three daughters live in Istanbul with their husbands. The oldest son lives in America with his family, and the second son lives in Istanbul with his family. The son in America has been to see his parents about three times in the last 10 years. The other son in Istanbul has not been to the village in years and has had economic problems in Istanbul. The Istanbul son's wife detests village life and villagers. When Semra went to Istanbul to visit them several years ago, this is what happened.

One night we went to a family gathering, just Semhat [her daughter-in-law], the kids and I. While we were there, they left without telling me. My brother, who also lives in Istanbul, gave me a ride back to the house. When I got back to the house, the door was locked, and I couldn't get in. I think they were there, but they wouldn't let me in. So my brother drove me to my oldest daughter's house (she also lives in Istanbul). I swore I wouldn't go back. But then this summer I was having a pain in my head. The doctor in town didn't know what it was, so I needed to see a doctor in Istanbul. I was going to stay with my oldest daughter, but my younger daughter said it would be insulting to my son if I did that. So I went to my son's house again, and after a few days my daughter-in-law said she wanted me to leave. So I called my daughter and her husband came and got me.

When I asked Semra whether she thought she could live with her other son who lives overseas if she needed to, she did not think it was likely. Although she gets along with this daughter-in-law, whom she has only met two or three times, she knows that life would be too different.

What would I do all day? Both my son and his wife work and the children are in school. I don't speak their language; my daughter-in-law and the children don't speak Turkish. I don't know how to cook their food, and maybe they wouldn't eat mine.

As to the son in Istanbul, she knows that moving there (even if they let her) would destroy any control or power she has over her life or the lives of others. She would be going to live in her daughter-in-

Journal of Aging Studies, Vol 15, No. 4 (December 2001): pg. 383-406. DOI. This article is (C) Elsevier and permission has been granted for this version to appear in e-Publications@Marquette. Elsevier does not grant permission for this article to be further copied/distributed or hosted elsewhere without the express permission from Elsevier. 
law's house in an unfamiliar city, and she knows that would change the power dynamics to favor the daughter-in-law. In some extreme cases, this might increase the incidence of elder abuse. (Once again, because some of these elderly lack what they think they want, they can easily idealize what they desire and forget that the reality would be a mixture of advantages and disadvantages. Saliye, who earlier told us how she used to obey her in-laws as a young bride, forgets that while being elderly in the home of your son may give you some power, in some cases, it may be limited. Saliye's daughter confided in me that she remembered her paternal grandfather saying from time to time, "God, please do not let me become sick under the care of my daughter-inlaw." Even daughters-in-law can take some revenge under certain circumstances.)

Another elderly woman suggested that this increased autonomy for daughters-in-law is one reason why it is unlikely that the village will rejuvenate in population.

The problem is that our sons get educated or move away for jobs. Then they end up marrying women who don't know how or don't want to do village work. Even if they marry a woman from a village family, she won't want to return to the village.

Erman's (1998) study of village migrant women in Ankara and Morvaridi's (1992) study of village women in northeast Turkey support such an observation. Erman found (p. 163) that most of the young migrant women had "shed some aspects of oppression by moving away from the control of in-laws and the strict norms of the village, and for the first-generation migrant women, this is a major source of satisfaction." About 95\% of Erman's sample of women preferred to remain in the city despite difficulties they faced (p. 159). Morvaridi ( $p$. 582 ) found that most of the village women she interviewed preferred "to escape to live in the city." 


\subsection{Health and economic well-being when life expectancy is increasing but family members are disappearing}

Retirement is a fairly novel concept to these elderly. In the past, most elderly worked on the farm until their death. Although many are living longer, for most of them, the physical energy and strength needed for farm work has surpassed the abilities of their deteriorating bodies (although one 80-something widower who lives by himself all year in the village continues to cut and bail his own hay). Therefore, because few young people are around to do the farm work, either the grandparents must continue to do the labor alone or they must cut back on their holdings. Most of them have reduced their herd sizes to one or two cows, and they have sold some of their land or let the land lie fallow.

This can make them vulnerable to others in the village who have tractors and can still farm. One man, Ziya, explained:

If I keep a few cows for milk and cheese and yogurt, I still have to sow at least one field for alfalfa to feed the cows. But I'm too old to harvest the alfalfa myself, so then I have to arrange with one of the tractor-owning families to cut down the alfalfa. Either I have to pay him cash or share the crop with him in payment for his services. I prefer to give him some of the alfalfa, because I don't have much cash. But tractor owners often have enough crop of their own, so they prefer the cash. Also the tractor owners don't want to waste their time on small plots of land. Sometimes those tractor owners know who is too old to cultivate their outlying plots of land, so they sometimes take over the land without the owner's permission because there is little the old owner can do about it.

Many elderly resent that they now have to part with some cash to accomplish things their family members used to do for them. This contradicts the values of reciprocity and obligation they grew up with and makes them more vulnerable to the market system.

One assumption I went into this with was that probably the people left behind were at least benefiting financially from the

Journal of Aging Studies, Vol 15, No. 4 (December 2001): pg. 383-406. DOI. This article is (c) Elsevier and permission has been granted for this version to appear in e-Publications@Marquette. Elsevier does not grant permission for this article to be further copied/distributed or hosted elsewhere without the express permission from Elsevier. 
migration of their children. ${ }^{6}$ One can see a proliferation of television sets, boomboxes, furniture, even a satellite dish or two, and other household appliances in the village, but it is difficult to discern how much of this is due to money or gifts coming from migrant children since even families without migrant children have some of these consumer products. About four or five houses have recently been built with remittances. One elderly man was eager to show me the new house he was in the process of building, but three of the new houses are not for these elderly. Instead, they lie empty, waiting for the migrants' return.

I did not reach a level of comfort with the villagers to feel free to discuss in great detail their financial situations. However, I did sense that expectations in this area are high, especially for migrant children overseas. The elderly who have not traveled much often think that everyone in Germany or America is rich. Although one overseas son had purchased furniture, wired cash, paid for an operation, and sent his parents on a 3-month pilgrimage to Mecca, one of the family members thought he should have bought one of his siblings a car also!

Although a number of studies indicate that economic aid is just as likely to flow from parent to child as it is in the opposite direction (Grundy \& Harrop, 1992), I was not expecting that to be the case in Sirna. I was surprised at the amount of agricultural goods that flow from the villages to migrant children in the cities (and occasionally overseas when those children return for a visit). It is quite common that the elderly parents in Sirna send kilos of bulgur, flour, and cheese to the cities for their children. Even the elderly who come back to the village in the summer will return to Istanbul with some agricultural products. Much of these products are stored in a cold, locked cave in the village. Several times a year, the village sends a truckload of these goods to Istanbul, where the driver delivers them to each household. The receiving household pays the driver for his services, but the products are gifts from the village.

In terms of health, the elderly villagers complain about their aches and pains and chronic illnesses, in good part because there is little else to do. In fact, it was often difficult to keep the interviews on issues of parent-child relationships, because many of them wanted to

Journal of Aging Studies, Vol 15, No. 4 (December 2001): pg. 383-406. DOI. This article is (C) Elsevier and permission has been granted for this version to appear in e-Publications@Marquette. Elsevier does not grant permission for this article to be further copied/distributed or hosted elsewhere without the express permission from Elsevier. 
talk about their various ailments. Most of them have bagfuls of numerous prescriptions that they have picked up from various doctors in town. Since most of them are illiterate, however, they often do not know what they are supposed to do with these pills or ointments, how often or how many they are supposed to ingest. One day, one family's son who had a doctorate degree (not a medical doctor) was returning to the village for a short visit with his family. Many of the elderly paid a visit to greet the man they knew as a child. He told me later that, about 10 min into the conversation, they would seek medical advice from the "doctor," even though he tried to explain that he was not that kind of doctor.

Tied to their health concerns are their worries about "the future." Although many of the elderly I interviewed had already lived beyond their life expectancy, their comments reflected unsettled conceptions of late life. A reflection of their concept of age occurred during one group conversation in which I was explaining that people in America try to save up a lot of money for their retirement. They asked me at what age people retire, and I replied that the standard was 65 . One man said, "Well, then they only need money for a few years." When I explained that it is not uncommon for people to live another 15-30 years in retirement, the group looked shocked. Nevertheless, their increasing concern over the possibility of lingering ill health in a context where sons and daughters-in-law are not around to attend to them reflects their growing awareness of the impact of these demographic and social changes.

"What will we do if something goes wrong?" was a question I heard repeatedly. They meant what if one or both of them becomes unable to function, who will help them? Many of them do not have children nearby. Istanbul is a 12 -h bus trip, and so the adult children residing there seem about as inaccessible as their children in Germany or America. There are no medical facilities in the village. There are few, if any, nursing homes in Turkey, so they know that in case of serious health problems, either their children would have to return to the village (which they know is unlikely) or they would have to move to Istanbul, an option not always appealing for reasons that will be discussed shortly.

Journal of Aging Studies, Vol 15, No. 4 (December 2001): pg. 383-406. DOI. This article is (C) Elsevier and permission has been granted for this version to appear in e-Publications@Marquette. Elsevier does not grant permission for this article to be further copied/distributed or hosted elsewhere without the express permission from Elsevier. 
One 70-year-old woman indicated that life was already becoming a burden she did not know if she could handle much longer. Her husband, who is about 10-12 years older than she, is declining in health. He has lost the sight in one eye and some of his hearing. Although he has no chronic health problems at this time, he moves slowly and has become preoccupied with his spiritual life in preparation for death. Although it would take him longer to do the household and farm chores (they only have one cow and a few chickens now, and they only grow alfalfa in one field), he probably could do more than he does. Perhaps, thinking of the woman who committed suicide, his wife complains frequently (even in her husband's presence, perhaps assuming he cannot hear or hoping to embarrass him into action):

I have to do everything for him now - cook for him, clean the house, feed him, get him a glass of water, bathe him, get the wood for the fire to warm the water, and clean the barn. Occasionally, she tops off her litany of the things she has to do for him with "I even have to trim his pubic hair!"

\subsection{Competing views of village life}

While a longer late life is fraught with anxiety, retirement has its benefits. Several factors now enable them to have at least a few years of a retirement. Their cash needs are still relatively small if they live in the village, and the government provides a small stipend for social security. Some of their migrant children provide some cash from their wage labor; and some of the elderly still have their basic food needs met by their small production. Lastly, a few of the men were among those first waves of male-only labor migrants to Europe in their youth. Several of the men I talked to had worked in Germany for 10-20 years and remigrated with some savings. Consequently, the ways the elderly view their community and redefine their status in the community are changing somewhat to adapt to the possibility of a "retirement."

Going to Istanbul for the winter is in one way becoming a new form of status; those who go to live with or near their children can boast to others that their sons have done well enough (even if they have not done so well) that the grandparents can "retire," essentially travel between two homes, and hopefully be provided for. It is not

Journal of Aging Studies, Vol 15, No. 4 (December 2001): pg. 383-406. DOI. This article is (C) Elsevier and permission has been granted for this version to appear in e-Publications@Marquette. Elsevier does not grant permission for this article to be further copied/distributed or hosted elsewhere without the express permission from Elsevier. 
uncommon to hear something similar to what one woman in her 60s, Nuriye, said:

When I'm in my son's house, the food that I eat is in front of me and the food I don't eat is on my side. [By this, she intends to imply that her son has done well and has plenty of food to offer her; she is well provided for.]

Those who remain in the village all year round feel somewhat jealous of their counterparts who appear to be welcomed into the homes of their son and who get to see their children and grandchildren most of the year. Also, the absence of so many villagers in the winter months, when visiting one another would be the main entertainment, contributes to their feeling of isolation. Samiye's words reflect the mixed feelings about this trend.

I don't like the big city; it's crowded and dirty. But I know if I don't go there for the winter, when will I see my grandchildren? My children work all day and their kids are in school, and they are far from here. They can't come to the village to visit very much. So we go there. Our grandson has gotten used to sleeping in our bed when we are in Istanbul, so now he is staying with us in the village for the summer.

Saliye, who stays in the village all year, nodded in agreement, acknowledging that contact with grandchildren was a benefit she lacked. A grandmother of 23 children, she says,

Some of my grandchildren I have only seen a couple times. I see my daughter's children the most because she lives in a nearby town. I miss having grandchildren around to carry on my back.

However, wintering with the children in Istanbul is not always the rosey story it appears to be. The husband of one couple, Sevkat and Aise, now in their mid-70s, had worked in Germany for 20 years when he was younger. The isolated existence he lived while in Germany is evidenced by the fact that he cannot speak more than one or two words of German. Nevertheless, he does have an air of experience that most of the other elderly villagers lack, which was first apparent to me when he and his wife refused my offer to lift their

Journal of Aging Studies, Vol 15, No. 4 (December 2001): pg. 383-406. DOI. This article is (C) Elsevier and permission has been granted for this version to appear in e-Publications@Marquette. Elsevier does not grant permission for this article to be further copied/distributed or hosted elsewhere without the express permission from Elsevier. 
hands to my chin and forehead upon our first meeting. Doing so is a traditional sign of veneration for the elderly in the village. Many villagers, especially the women, will lift their hands for you if it appears that you intend to only shake their hands. When I suggested during an interview with this couple that perhaps the migration of children benefited parents by allowing them to move out of the village, this couple laughed. "Most villagers are uneducated," Sevkat, the husband, prefaced.

Their sons go off to Istanbul uneducated too. They often aren't doing that well in Istanbul, but when their parents ask "What are you doing?" or "How much are you making?," the sons exaggerate. Even if they tell the truth, the parents don't know enough anyway to understand how little money it is. So the parents get all excited. They tell their friends. They decide to pack up and move to Istanbul too. They sell their cows, chickens, the roof over their heads [He means this literally, because the roofs of the houses are often made of huge logs of solid pine or birch that are costly in the village, so they dismantle the roofs and sell them piece by piece.] and sometimes their land. They go off to Istanbul to find that they must rent a small apartment near their son because their son's apartment is too small. After a year or so, the money runs out. They must be satisfied to eat the breadcrumbs their son gives them and drink their leftover tea. They know if they complain, they will be told to return to the village, where they now have nothing to live on.

Most of the elderly who winter in Istanbul return to the village with complaints about life in Istanbul. The two most frequent adjectives used in reference to Istanbul are pis (dirty) and kalabalik (crowded). Istanbul actually has a number of beautiful neighborhoods and historical sites, but many of these elderly are the parents of children who are squatters or live in low-income neighborhoods in the city. ${ }^{7}$ In addition, the pace and unfamiliarity of urban life is overwhelming to them, so when they are in Istanbul, they rarely explore the various attractions of the city. Instead, they counter these descriptions of Istanbul with descriptions of the village as cok guzel (very beautiful). Most outsiders would find the village itself, located in a valley, anything but cok guzel. The village's rutted, narrow roads are frequently filled with sewerage and cow manure. However, just outside

Journal of Aging Studies, Vol 15, No. 4 (December 2001): pg. 383-406. DOI. This article is (C) Elsevier and permission has been granted for this version to appear in e-Publications@Marquette. Elsevier does not grant permission for this article to be further copied/distributed or hosted elsewhere without the express permission from Elsevier. 
the village, on every mountain slope, are golden fields of wheat and vivid wildflowers. I assumed it was these to which they referred.

On the other hand, juxtaposed to the statements about the crowded, dirty cities and the beautiful village are new perspectives on village life. While the elderly still idealize what village life was like the extended family, the respect from sons and daughters-in-law, the joy of grandchildren, and the interaction of more people in the village, in other ways, they have reevaluated what the village has to offer. For example, one day I told my two daughters that they could go out by themselves and explore the village. One woman warned me, "They better be careful, the village is a children's graveyard."

The elderly, women in particular, know that life in the village is hard. Semra complained,

When I was young and married into my husband's household, I was out working in the field or cooking dinner with one child in my stomach and another on my back. It wasn't easy.

Yet, this same woman complains that her daughter-in-law in Istanbul

thinks she is better than us villagers. When she comes here, which is rare, she refuses to help do any work. And when we send her food [bulgar or cheese primarily] from the village, she throws it away. She wants to pretend she isn't one of us, even though her family originally came from a village.

Another aspect of village life that seems to raise contradictory reflections is the issue of morality and community enforcement of the norms. While many complain that they have little say over their children's decisions and their grandchildren's discipline, the elderly villagers are aware that the norms of the village and the fact that everyone knows, or thinks s/he knows, what everyone else is doing can be oppressive. This is even more so true since the population in the village has declined; it is much easier to keep tabs on everyone. Moreover, the villages are relatively isolated from bureaucracy and law enforcement of the cities, so people in the village can institute their 
own norms (even those contrary to religious teachings) and take care of their own problems with little interference from government.

Most of the supervision and talk is relatively harmless. One woman complained

My sister-in-law was spreading rumors that in the winter we burn thin willow twigs for heat [a sign of poverty], and someone else reported me to the mayor because I used the village water [illegally] to water my vegetable garden. You can't do anything around here without someone saying something.

While I was there, I accompanied some women to the village oven to watch them make bread. Each woman brings a large bucket of dough, sometimes enough to make bread for a month. The women usually help each other form and bake the dough. They may spend hours there talking. The day I was there, one young "uppity" woman had started baking her loaves of bread before it was her turn. All of the women began talking aloud among themselves about how it was wrong to do that, who did she think she was, and how it had upset the schedule. The young woman was undeterred, however, by their rebuke. She continued until she was finished, picked up her basket of baked loaves, and walked out.

However, some talk has more serious consequences. One woman told me the following story.

A few years ago one of the men in the village [an older married man with adult children] began going around the village bragging that he had had sex with various married women in the village. [It was unclear whether he meant they had had affairs or whether he had raped them.] All the women said it wasn't true [which it was presumed they would do whether or not they had had sex with him and whether it had been mutual or rape]. He then began threatening to do the same with some other women in the village. So one day while he was out in the field, a group of men from outside the village attacked and killed him, cut off his penis, and stuck it in his mouth.

Needless to say, I was quite surprised to hear this story, ${ }^{8}$ but the others who were in the room seemed to think it was the appropriate way to handle the situation. Even the dead man's son, 
who is currently the village's bus driver and whom I talked to several days later, said (as if it were regrettable yet understandable) "My father was a victim of his mouth."

Consequently, despite the regrets and fears that many of the elderly expressed during these conversations, when I asked the elderly whether they wished their children had not left the village, not one would say he or she regretted it. One woman told me the story of her extended family feud as a way of explaining why she preferred that her children left.

At one time my husband's and his brother's families shared the household and pooled their land holdings. They were considered one of the wealthier villagers during those years. However, conflicts over the land and household resources grew to such an extent that my brother-in-law, who is younger than my husband, beat up their father and then a few years later beat up my husband. It was all because of arguments over the land. Of course, we eventually separated, but they still live next door to us. Neither of us have any children living in the village now. They have a tractor and we don't. Now we have to pay him to help us, and sometimes he says no.

I heard several stories like this. Therefore, two different women had the same comment when asked whether they wished their children remained in the village. "If they had, they would have eaten each other."

"There is nothing for them here in the village," said one grandmother, shaking her head as if acknowledging that even her children's mother is not enough to draw them back to the village. Another woman added, "Day in and day out, we have our hands in the soil, cow shit, or the mud of the village streets. That is our life here." Also, one man said, "The village is like a donkey with a cut tail. No matter what you do, it never gets longer or shorter." Another woman summed up the future of the village: "The young people will leave, and the old people will die with the village." Although she said that with disappointment and others present at the time nodded in agreement, somehow, between the family feuds over scarce resources, the oppressive control, and hard life, they are reconciling to the fact that village life has lost its appeal to the younger generations.

Journal of Aging Studies, Vol 15, No. 4 (December 2001): pg. 383-406. DOI. This article is (C) Elsevier and permission has been granted for this version to appear in e-Publications@Marquette. Elsevier does not grant permission for this article to be further copied/distributed or hosted elsewhere without the express permission from Elsevier. 


\section{Discussion}

While a few of these elderly narrators point out the poignant disadvantages of traditional life and, in so doing, mitigate uncontrolled fantasy and disappointment among the group, the tangle of contradictions that these elderly villagers must live with is intensified by their inclination to remember and narrate mostly the benefits of traditional kin relations. This romanticized past juxtaposed against the disappointing present and these old expectations incongruent with new circumstances are to some degree the contradictions that parents all over the world must deal with. Parents want their children to do as well or better than they did. They want their children to succeed and they want to be able to boast of their children's accomplishments to their peers. However, those accomplishments often have a price migration away from home, less control over the lives of children, and sometimes painful adjustments in family relations and obligations.

Yet, these Turkish elderly are in the midst of a widespread upheaval in social and economic forces, similar to the one that occurred in the United States as the country transformed from an agricultural economy to an industrial economy. Family sociologists Coontz (1997) and Skolnick (1993) have written about families during times of social and cultural transformations. They point out that ways of thinking about and doing family often lag behind the structural changes that occur in the economy. Hence, people's attempts to live by the old ways and expectations under new circumstances that are no longer conducive to those old ways only lead to frustration and, frequently, create more problems. Once people begin to understand the changes, they can begin to adapt their expectations and family traditions to the new realities. They may be able to retain the old values but must implement them through new means.

For these Turkish elderly, their agricultural lifestyle and the idealized patrilocal extended family are declining, while their life expectancy is increasing. They fear that their children have rejected their parents and their way of life. They now fear the years that they once looked forward to as a time to have status through control over and respect from nearby family members. Though more are educating

Journal of Aging Studies, Vol 15, No. 4 (December 2001): pg. 383-406. DOI. This article is (C) Elsevier and permission has been granted for this version to appear in e-Publications@Marquette. Elsevier does not grant permission for this article to be further copied/distributed or hosted elsewhere without the express permission from Elsevier. 
their daughters, they have not yet fully recognized the value their daughters will eventually have in their lives. Some, such as the woman who committed suicide, have become victims of these tumultuous times. ${ }^{9}$

However, there are signs that the elderly are comprehending and adjusting to the changes. The interaction and multitude of their narratives enables them to manage their new circumstances, limit their fears, and see alternative ways of adapting to these transitions. For instance, although most do not desire to live overseas or leave the village entirely, there is an increased willingness to relocate in order to spend at least part of each year with family members. They do this despite the fact that they know the family arrangements will not likely be on their terms, as it would have been had the son and daughter-inlaw come to live with them. They are redefining status as that attained through family contact (as opposed to family residence and control), through the ability to have some form of retirement (rather than remaining productive in the family setting), and through the accumulation of consumer goods (rather than land holdings and family size). Finally, they seem to understand that the need for, and the actual attainment of, educational and economic opportunities for their children rather than a lack of care on the part of their children has made their children unsuited for village life. Though they resent disdainful attitudes toward village life, they see its shortcomings.

As a case study, this article raises more questions for further research. Filial responsibilities - what it means to be a good son or daughter - are obviously socially constructed over time and space. It is unlikely that filial responsibility will die as a value but more likely will take on new forms and meanings. To what extent will those new forms of filial obligations influence gender valuation, and in what ways will filial behavior be situated by its urban and rural contexts?

As people live longer and married couples have more time together without children, attitudes about marriage change. How are marital relations and division of labor affected among these rural elderly couples? Is life and/or marital satisfaction among the elderly whose children have migrated higher or lower than satisfaction among

Journal of Aging Studies, Vol 15, No. 4 (December 2001): pg. 383-406. DOI. This article is (C) Elsevier and permission has been granted for this version to appear in e-Publications@Marquette. Elsevier does not grant permission for this article to be further copied/distributed or hosted elsewhere without the express permission from Elsevier. 
those who live in extended households or those who live nearby their children?

Given the likelihood that Turkish village life will become a parttime experience for a substantial proportion of the elderly for some time, a more systematic comparison between full-year and part-year villagers would be useful. What attitudinal and behavioral changes are incurred among the elderly who live part of the year in the city and part in the village? What type of "biculturalism" do the part-timers experience? In what ways are filial expectations modified differently according to whether their children are internal or external migrants?

In short, there is ample room for research in these areas of filial relations in the context of late life and migration. Hopefully, this exploratory study offers an impetus for more systematic studies. Given the extent and pace of migrations around the world, more needs to be done on how migration affects cultural changes in the sending countries rather than merely focusing on the migrants in the recipient countries. Likewise, rural-to-urban migration studies need to focus more on the rural regions rather than merely on the cities. Also, the perspective and voice of those who remain in the villages needs to be treated as important rather than viewed as just the residue that the adventurous migrant leaves behind. The ability of most of these elderly to surmount these changes and make some modifications at this late stage in their lives is a tribute to the power of the human narrative and the resiliency of family relations.

\section{Acknowledgments}

The author is grateful to Selami Dogan for contacts and translation services, to the elderly who willingly shared their fears and frustrations, and to the anonymous reviewers for their insightful comments.

\section{References}

Akcelik, R. \& Elley, J. (1988). Turkish community in Australia. Conference papers. Mulgrave North, Victoria: Australian-Turkish Friendship Society.

Al-Hamad, A., Flowerdew, R., \& Hayes, L. (1997). Migration of elderly people to join existing households: some evidence from the 1991 Household

Journal of Aging Studies, Vol 15, No. 4 (December 2001): pg. 383-406. DOI. This article is (C) Elsevier and permission has been granted for this version to appear in e-Publications@Marquette. Elsevier does not grant permission for this article to be further copied/distributed or hosted elsewhere without the express permission from Elsevier. 
Sample of Anonymised Records. Environment and Planning A, 29 (7), 1243-1255.

Aycan, Z., \& Kanungo, R. N. (1998). Impact of acculturation on socialization beliefs and behavioral occurrences among Indo-Canadian immigrants. Journal of Comparative Family Studies, 29 (3), 451-468.

Becker, G., \& Beyene, Y. (1999). Narratives of age and uprootedness among older Cambodian refugees. Journal of Aging Studies, 13 (1), 295-314.

Bloom, D. E., \& Brender, A. (1993). Labor and the emerging world economy. Population Bulletin, 48 (2), 1-39.

Bruner, J. (1986). Actual minds, possible worlds. Cambridge, MA: Harvard University Press.

Bruner, J. (1996). The culture of education. Cambridge, MA: Harvard University Press. Bruner, J. (1999). Narratives of aging. Journal of Aging Studies, 13 (1), 7-9.

Cataltepe, S. (1999, July). Secretary at Zara Ahmed Cuhadaroglu Meslik Yuksek School. Interview.

Coontz, S. (1997). The way we really are. New York: Basic Books.

Duben, A. (1985). Turkish families and households in historical perspective. Journal of Family History, 10 (1), 75-97.

Ekmek-Cioglu, Z. (Ed.). (1998). Cumhuriyetimizin 75. Yilinda Sivas. Ankara: Baski.

Erman, T. (1998). The impact of migration on Turkish rural women: four emergent patterns. Gender and Society, 12 (2), 146-167.

Faragallah, M. H., Schumm, W. R., \& Webb, F. J. (1997). Acculturation of Arab-American immigrants: an exploratory study. Journal of Comparative Family Studies, 28 (3), 182-203.

Goldberg, A. (1996). The status and specific problems of elderly foreigners in the Federal Republic of Germany. Journal of Comparative Family Studies, 27 (1), 129.

Grundy, E., \& Harrop, A. (1992). Co-residence between adult children and their elderly parents in England and Wales. Journal of Social Policy, 21, 325-348.

Haddad, T., \& Lam, L. (1994). The impact of migration on the sexual division of family work: a case study of Italian immigrant couples. Journal of Comparative Family Studies, 25 (2), 167-182.

Ilcan, S. M. (1994). Peasant struggles and social change: migration, households, and gender in a rural Turkish society. International Migration Review, 28 (3), 554-579.

Johnson, P. J. (1998). Performance of household task by Vietnamese and Laotian refugees: tradition and change. Journal of Family Issues, 19 (3), 245-274.

Journal of Aging Studies, Vol 15, No. 4 (December 2001): pg. 383-406. DOI. This article is (C) Elsevier and permission has been granted for this version to appear in e-Publications@Marquette. Elsevier does not grant permission for this article to be further copied/distributed or hosted elsewhere without the express permission from Elsevier. 
NOT THE PUBLISHED VERSION; this is the author's final, peer-reviewed manuscript. The published version may be

accessed by following the link in the citation at the bottom of the page.

Kamo, Y., \& Zhou, M. (1994). Living arrangements of elderly Chinese and Japanese in the United States. Journal of Marriage and the Family, 56 (3), 544-558.

Karpathakis, A. (1999). Home society politics and immigrant political incorporation: the case of Greek immigrants in New York City. International Migration Review, 33 (1), 55-78.

Khaled, L. (1995). Migration and women's status: the Jordan case. International Migration, 33 (2), 235 -251.

Kiray, M. (1976). The new role of mothers: changing intra-familial relationships in a small town in Turkey. In: J. G. Peristiany (Ed.), Mediterranean family structures (pp. 261-271). New York: Cambridge University Press.

Kocturk, T. (1992). A matter of honour: experiences of Turkish women immigrants. Atlantic Highlands, NJ: Humanities Press International.

Koltyk, J. (1998). New pioneers in the Heartland: among life in Wisconsin. Needham Heights, MA: Allyn and Bacon.

Lee, G. R., \& Coward, R. T. (1994). Residential differences in filial responsibility expectations among older persons. Rural Sociology, 59 (1), 100-110.

Lee, G. R., \& Netzer, J. K. (1995). Depression among older parents: the role of intergenerational exchange. Journal of Marriage and the Family, 57 (3), 823-834.

Liebkind, K. (1996). Acculturation and stress. Journal of Cross-Cultural Psychology, 27 (2), 161-181.

Linde, C. (1993). Life stories: the creation of coherence. New York: Oxford University Press.

Mahirogullari, A. (1996). Dunden Bugune Zara. Sivas: Baski.

Mattingly, C., \& Garro, L. (1994). Introduction: narrative representations of illness and healing. Social Science and Medicine, 38, $771-774$.

McAdams, D. P. (1996). Narrating the self in adulthood. In: J. E. Birren, G. M. Kenyon, J. E. Ruth, J. J. F. Schroots, \& T. Svensson (Eds.), Aging and biography: explorations in adult development (pp. 131-148). New York: Springer.

Morvaridi, B. (1992). Gender relations in agriculture: women in turkey. Economic Development and Cultural Change, 40 (3), 567-587.

Noivo, E. (1993). Ethnic families and the social injuries of class, migration, gender, generation and minority. Canadian Ethnic Studies, 25 (3), 6676.

Olmedo, I. M. (1999). Redefining culture through the memorias of elderly Latinas. Qualitative Inquiry, 5 (3), 353-376.

Omran, A. R., \& Roudi, F. (1993). The Middle East population puzzle. Population Bulletin, 48 (1), 1-40.

Journal of Aging Studies, Vol 15, No. 4 (December 2001): pg. 383-406. DOI. This article is (C) Elsevier and permission has been granted for this version to appear in e-Publications@Marquette. Elsevier does not grant permission for this article to be further copied/distributed or hosted elsewhere without the express permission from Elsevier 
Onder, Z. (1996). Muslim-Turkish children in Germany: sociocultural problems. Migration World Magazine, 24 (5), 18-24.

Ortiz, V. (1996). Migration and marriage among Puerto Rican women. International Migration Review, 30 (2), 460.

Penny, J., \& Khoo, S. E. (1996). Intermarriage: a study of migration and integration. Canberra, ACT: Australian Government Publishing Service for the Bureau of Immigration, Multicultural and Population Research.

Poirine, B. (1997). A theory of remittances as an implicit family loan arrangement. World Development, 25 (4), 589-612.

Polkinghorne, D. E. (1988). Narrative knowing and the human sciences. Albany, NY: State University of New York Press.

Randall, W. L. (1999). Narrative intelligence and the novelty of our lives. Journal of Aging Studies, 13 (1), 11-28.

Rasuly-Paleczek, G. (1996). Some remarks on the study of household composition and intra-family relations in rural and urban Turkey. In: G. Rasuly-Paleczek (Ed.), Turkish families in transition (pp. 1-44). New York: Peter Lang.

Simons, M. (1989). Casualties of change in Italy: the old people left behind. The New York Times, 26, $1 \mathrm{ff}$ (August).

Skolnick, A. (1993). Changes of heart: family dynamics in historical perspective. In: P. Cowan, D. Field, D. Hansen, A. Skolnick, \& G. Swanson (Eds.), Family, self and society. Toward a new agenda for family research (pp. 52-56). Hillsdale, NJ: Lawrence Erlbaum.

State Institute for Statistics (1999). Republic of Turkey, Prime Ministry. Available on the World Wide Web at http://www.turkishstudies.org/f_useful.html.

Sussman, M. B., \& Settles, B. H. (1993). Policy and research issues regarding family mobility and immigration. Marriage and Family Review, 19 (34), $209-233$.

Thomas, T. (1992). Vietnamese elderly women in Australia: health issues. Unpublished paper presented at the Bureau of Immigration Research: Women in Migration Conference, Ormond College, University of Melbourne.

Tienda, M., \& Booth, K. (1991). Gender, migration and social change. International Sociology, 6, $51-72$.

Toro-Morn, M. I. (1995). Gender, class, family and migration: Puerto Rican women in Chicago. Gender and Society, 9 (6), 712-726.

Tunali, I. (1996). Migration and remigration of male household heads in Turkey, 1963-1973. Economic Development and Cultural Change, 45 (1), 31-67.

Turner, V. (1980). Social dramas and stories about them. In: W. J. T. Mitchell (Ed.), On narrative (pp. 137-164). Chicago: University of Chicago Press.

Journal of Aging Studies, Vol 15, No. 4 (December 2001): pg. 383-406. DOI. This article is (C) Elsevier and permission has been granted for this version to appear in e-Publications@Marquette. Elsevier does not grant permission for this article to be further copied/distributed or hosted elsewhere without the express permission from Elsevier. 
NOT THE PUBLISHED VERSION; this is the author's final, peer-reviewed manuscript. The published version may be accessed by following the link in the citation at the bottom of the page.

Vandsemb, B. H. (1995). The place of narrative in the study of third world migration: the case of spontaneous rural migration in Sri Lanka. Professional Geographer, 47 (4), 411-426.

\section{Endnotes}

${ }^{1}$ Akcelik and Elley (1988), Aycan and Kanungo (1998), Faragallah, Schumm, and Webb (1997), Goldberg (1996), Haddad and Lam (1994), Johnson (1998), Kamo and Zhou (1994), Karpathakis (1999), Koltyk (1998), Liebkind (1996), Noivo (1993), Onder (1996), Ortiz (1996), Penny and Khoo (1996), Sussman and Settles (1993), and Toro-Morn (1995) are just a small sample of those who have studied Latino, Turkish, and Asian migrants in Australia, Canada, Germany, and the United States.

2 When I speak of "Turks" here, I am not making a distinction between ethnic Kurds and Turks. Rather, I speak in terms of nationality. Therefore, one should not infer that only Turkish villages, as opposed to Kurdish villages, which are largely located in the east, are affected by these migrations. Kurdish villagers face dangers from both sides of the conflict. Kurdish guerrillas often come to the village to recruit young boys, and the Turkish army often attacks houses to flush out guerrillas or in revenge for terrorist attacks. So, Kurds also are leaving the villages of the east and moving west as well.

3 The country of Turkey lies partly on the European continent and mostly on the continent of Asia. Anatolia is the name given to the part of Turkey in Asia.

${ }^{4}$ Sirna was established 500 years ago, but it has only maintained population records (not very accurately) since the 1920s. The local population records are actually family lineages rather than actual counts. However, long-time residents tell me the population had been in their lifetime near 600.

5 See Kiray (1976), who thinks that this trend is leading to an intensification of the mother-daughter relationship. While I did see a couple cases of this, I did not notice that to be widespread in this village yet.

${ }^{6}$ Although remittances to Turkey totaled US\$2901 million in 1991 (Omran \& Roudi, 1993, p. 25), some studies indicate that remittances are less likely to be invested in the village sector and that those remittances, which do make their way to the village, are likely to be used for household consumption or for building a retirement home for the returning migrant. See Poirine (1997, pp. $589-590)$, for instance.

7 Many villagers moved to Istanbul or Ankara and built squatter housing on unclaimed land. These are appropriately called gecekondu, which essentially means "housing built at night." Only in the past 10 years or so has the Turkish government started taking each land-grab to court

Journal of Aging Studies, Vol 15, No. 4 (December 2001): pg. 383-406. DOI. This article is (C) Elsevier and permission has been granted for this version to appear in e-Publications@Marquette. Elsevier does not grant permission for this article to be further copied/distributed or hosted elsewhere without the express permission from Elsevier. 
to decide whether the residents will be allowed to stay and obtain official title to the property.

${ }^{8}$ A similar incident involved the Imam, whose religious commitment, I mentioned earlier, is suspect. About 15-20 years back, a man in the village spread a rumor (the veracity of which remains unverified) that the Imam, who was then engaged to his wife, had had sex with his mother-in-law to be (she was supposedly the most beautiful woman in the village at the time). Both the mother-in-law and the Imam denied the accusations. A few months later, the son of the man who spread the rumor was killed in a "gun accident" while playing with the son of the mother-in-law. To this day, no one knows if it really was an accident or whether it was payback for spreading the rumor. The mother-in-law died several years later. People think her death was premature due to the stress of the rumors.

9 Similarly, see Simons (1989), whose newspaper article about Italian rural elderly experiencing more neglect because of rural-to-urban migration indicates that the observations here are occurring elsewhere as well.

\section{Appendix}

\section{Table 1}

Ages (by decades) and marital status of elderly respondents

\begin{tabular}{|c|c|c|c|c|}
\hline Total [no. (\%)] & 50s [no. (\%)] & 60s [no. (\%)] & 70s [no. (\%)] & 80s [no. (\%)] \\
\hline $31(100)$ & $5(16)$ & $13(42)$ & $11(35)$ & 2 \\
\hline $\begin{array}{l}\text { Total } \\
\text { Households } \\
\text { [no. (\%)] }\end{array}$ & $\begin{array}{c}\text { Married } \\
\text { couples } \\
\text { [no. (\%)] }\end{array}$ & $\begin{array}{c}\text { Widow(er) } \\
\text { [no. (\%)] }\end{array}$ & $\begin{array}{c}\text { Divorced/separated } \\
\text { [no. } \\
(\%)]\end{array}$ & $\begin{array}{c}\text { Never married } \\
\text { [no. } \\
(\%)]\end{array}$ \\
\hline $20(100)$ & $11(55)$ & $8(40)$ & $1(5)$ & 0 \\
\hline
\end{tabular}

apercentages to not total to 100 because of rounding.

\section{Table 2}

Residential pattern of elderly by marital status

\begin{tabular}{|l|l|l}
\hline Marital status & Village year-round [no. (\%)] & Village in summer [no. (\%)] \\
\hline Married couples 11 & $6(55)$ & $5(45)$ \\
\hline Widows 7 & $4(57)$ & $3(43)$ \\
\hline Widow 1 & $1(100)$ & - \\
\hline Divorced/Separated 1 & $1(100)$ & - \\
\hline Total of 20 households & $12(60)$ & $8(40)$ \\
\hline
\end{tabular}

Journal of Aging Studies, Vol 15, No. 4 (December 2001): pg. 383-406. DOI. This article is (C) Elsevier and permission has been granted for this version to appear in e-Publications@Marquette. Elsevier does not grant permission for this article to be further copied/distributed or hosted elsewhere without the express permission from Elsevier. 
NOT THE PUBLISHED VERSION; this is the author's final, peer-reviewed manuscript. The published version may be accessed by following the link in the citation at the bottom of the page.

\section{Table 3}

\section{Living arrangements of elderly by marital status and full-year and part-year village residence}

\begin{tabular}{|l|l|l|l|l|l|l|l|l|l|l|}
\hline \multicolumn{9}{|l|}{ Year round village } & \multicolumn{3}{l|}{ Summer village } \\
\hline \multicolumn{2}{|l|}{$\begin{array}{l}\text { When in Istanbul } \\
\text { Sarital }\end{array}$} & $\begin{array}{l}\text { Lives } \\
\text { with } \\
\text { son }\end{array}$ & Alone & Daughter & $\begin{array}{l}\text { Marital } \\
\text { status }\end{array}$ & $\begin{array}{l}\text { Lives } \\
\text { with } \\
\text { son }\end{array}$ & Alone & Daughter & $\begin{array}{l}\text { Lives } \\
\text { with } \\
\text { son }\end{array}$ & Alone Daughter \\
\hline MC 6 & 1 & 5 & 0 & MC 5 & 2 & 3 & 0 & 1 & 4 & 0 \\
\hline Widow 4 & 3 & 1 & 0 & $\begin{array}{l}\text { Widow } \\
3\end{array}$ & 2 & 0 & 1 & 1 & 2 & 0 \\
\hline Widower & 0 & 1 & 0 & & & & & & & \\
\hline Divorced & 0 & 1 & 0 & & & & & & & \\
\hline Total 12 & 4 & 8 & 0 & Total 8 & 4 & 3 & 1 & 2 & 6 & 0 \\
\hline
\end{tabular}

